\title{
Low-Temperature Curable Dielectric Materials with Higher Reliability
}

\author{
Takuya Komine*, Akitoshi Tanimoto, Yu Aoki, Mika Kimura, Yoshimi Hamano, and \\ Mamoru Sasaki
}

\author{
Photosensitive Materials R\&D Dept., Electronics-related Materials Development Center, \\ R\&D Headquarters, Hitachi Chemical Co., Ltd., 4-13-1 Higashi-cho, \\ Hitachi-shi, Ibaraki 317-8555, Japan \\ *taku-komine@hitachi-chem.co.jp
}

\begin{abstract}
Semiconductor packages with redistribution layers have been necessary with their miniaturization and functionalization. Dielectric materials for the packages require lowtemperature curability to avoid thermal damage of devices and thermally unstable materials in the packages, and to keep high reliability for various thermal tests. Low-temperature curable positive-tone photosensitive material AR-5100 was developed and its reliabilities were evaluated. AR-5100 kept mechanical properties after reliability tests. Especially, AR5100 had good bias HAST tolerance. AR-5100 is capable of adapting to next-generation packages which require high reliability.
\end{abstract}

Keywords: Low-temperature curable, Photosensitive, Reliability, Resolution

\section{Introduction}

Semiconductor devices have progressed along with the decrease of package size and the increase of $\mathrm{I} / \mathrm{O}$ counts. Also, semiconductor package designs have been complicated because of miniaturization and high performance. Therefore, semiconductor packages which have redistribution layer have become necessary. By the application of redistribution layers, devices are possible to increase I/O counts and show high performance with low energy consumption. These packaging techniques require dielectric materials which can be cured at low temperature with high resolution. In addition, since the number of redistribution layers is increasing, dielectric layers need to have low residual stress to avoid device warpage, and also to have high reliability for various thermal tests.

Polyimide (PI) and polybenzoxazole (PBO) have widely been applied as dielectric layer materials for semiconductors [1]. However, there are several disadvantages such as thermal damage of device and wafer warpage with conventional PI and PBO which need to be cured at high temperature. Low temperature curable PI and PBO have been developed to satisfy the requirements from recent packages $[2,3]$.
We have focused on low-temperature curable photosensitive material utilizing phenol resin. In previous study, we reported positive-tone photosensitive dielectric material $\mathrm{AH}-1170$ and $\mathrm{AH}-$ 3000 for redistribution layers [4,5]. However, phenol resin has been inferior to PI and PBO in reliability.

In this paper, we report a novel photosensitive dielectric material AR-5100, which is positive tone, aqueous developable and low-temperature curable with improved reliability. Compared with standard AH series, an imide-modified elastomer is utilized for AR-5100, which enables higher reliability for various thermal tests.

\section{Experimental}

2.1. Lithographic properties

AR-5100 and AH-3000 were coated on 6-inch Si wafers with a spin-coater (Mark-7, Tokyo Electron) and soft-baked at $120{ }^{\circ} \mathrm{C}$ for $3 \mathrm{~min}$ on a hot plate of Mark-7. Then the film was exposed with an i-line stepper (FPA-3000i, Canon) and developed in $2.38 \%$ TMAH at $23{ }^{\circ} \mathrm{C}$. The patterned films were cured in an oven (INH-9CD-S, Koyo Thermo Systems) under $\mathrm{N}_{2}$ atmosphere. 


\subsection{Mechanical properties}

Elongation, tensile strength and Young's modulus of $10 \mu \mathrm{m}$ thick cured film were measured using a tensile testing machine (AGS-100NH, Shimadzu).

\subsection{Residual stress}

The initial warpage of a 6-inch wafer was measured with a film stress measurement system (KLA-Tencor). Then, AR-5100 or AH-3000 was coated on the wafer and cured. The warpage of cured wafer was measured with the system and its residual stress was calculated.

\subsection{Measurement of thermal properties}

Glass transition temperature $(T \mathrm{~g})$ and coefficient of thermal expansion (CTE) of cured film were measured with a thermomechanical analysis (TMA/SS7100 SII).

\subsection{Adhesion strength with $\mathrm{Cu}$}

AR-5100 and AH-3000 were coated on Cu-plated wafers and cured at $230{ }^{\circ} \mathrm{C}$. Then the wafers were treated with thermal cycle $\left(-55^{\circ} \mathrm{C}\right.$ to $\left.125{ }^{\circ} \mathrm{C}\right)$ and high temperature storage (HTS) $\left(150{ }^{\circ} \mathrm{C}\right)$. An aluminum stud with epoxy resin was placed on the treated film and heated at $150{ }^{\circ} \mathrm{C}$ for $60 \mathrm{~min}$. Adhesion strength was measured by pulling the aluminum stud with an universal materials tester (Romulus, Quad Group).

\subsection{Bias HAST test}

AR-5100 and AH-3000 were coated on a test piece structure (Fig. 1) and cured at $230{ }^{\circ} \mathrm{C}$. Then the test piece was treated with bias HAST (bHAST) test $\left(135{ }^{\circ} \mathrm{C} / 85 \% \mathrm{RH} / 3.3 \mathrm{~V}\right)$. This test was conducted with an ion migration tester(MIG-8600, IMV).

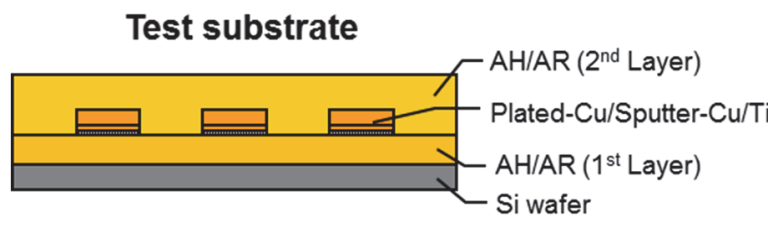

Fig. 1. Test piece structure of bias HAST test.

\section{Results and discussion}

\subsection{Lithographic properties}

The lithographic properties of AR-5100 are shown in Table 1. AR-5100 showed excellent resolution of 2 to $3 \mu \mathrm{m}$. Film retention after development was over $90 \%$. This is attributed to strong interaction between the base resin and the photoactive compound, which results in strong dissolution inhibition of the unexposed area at development.
AR-5100 is applicable for a wide range of cured film thickness by modifying material viscosity or rotation speed at spin-coating process.

Table 1. Lithographic properties of AR-5100.

\begin{tabular}{|c|c|c|c|c|}
\hline Items & Units & \multicolumn{3}{|c|}{ AR-5100 } \\
\hline $\begin{array}{c}\text { Coated } \\
\text { film } \\
\text { thickness }\end{array}$ & {$[\mu \mathrm{m}]$} & 6.2 & 11.9 & 18.5 \\
\hline Resolution & {$[\mu \mathrm{m}]$} & 2 & 2 & 3 \\
\hline $\begin{array}{c}\text { Exposure } \\
\text { dose }\end{array}$ & {$\left[\mathrm{mJ} / \mathrm{cm}^{2}\right]$} & 260 & 380 & 500 \\
\hline $\begin{array}{c}\text { Development } \\
\text { time }\end{array}$ & {$[\mathrm{sec} / \mathrm{time}]$} & $30 / 2$ & $60 / 2$ & $60 / 2$ \\
\hline $\begin{array}{c}\text { Developed } \\
\text { film thickness }\end{array}$ & {$[\mu \mathrm{m}]$} & 5.6 & 11.0 & 16.7 \\
\hline $\begin{array}{c}\text { Cured film } \\
\text { thickness }\end{array}$ & {$[\mu \mathrm{m}]$} & 5.0 & 10.0 & 15.0 \\
\hline
\end{tabular}

\subsection{Film properties}

Mechanical properties and thermal properties of AR-5100 and AH-3000 are shown in Table 2. The elongation and the tensile strength of AR-5100 are higher than those of AH-3000. This is attributed to the introduction of imide structure to elastomer. The modification improved toughness by the interaction between the imide moiety and the base resin. On the other hand, the residual stress of AR-5100 is low enough as well as AH-3000.

Table 2. Film properties of AH-3000 and AR-5100.

\begin{tabular}{|c|c|c|c|}
\hline Properties & Unit & AH-3000 & AR-5100 \\
\hline $\begin{array}{c}\text { Film } \\
\text { thickness }\end{array}$ & {$[\mu \mathrm{m}]$} & 10 & 10 \\
\hline Resolution & {$[\mu \mathrm{m}]$} & 3 & 2 \\
\hline $\begin{array}{c}\text { Curing } \\
\text { temperature }\end{array}$ & {$\left[{ }^{\circ} \mathrm{C}\right]$} & 230 & 230 \\
\hline Elongation & {$[\%]$} & 46 & 60 \\
\hline $\begin{array}{c}\text { Tensile } \\
\text { strength }\end{array}$ & {$[\mathrm{MPa}]$} & 110 & 160 \\
\hline $\begin{array}{c}\text { Young's } \\
\text { modulus }\end{array}$ & {$[\mathrm{GPa}]$} & 2.4 & 2.4 \\
\hline $\begin{array}{c}\text { Residual } \\
\text { stress }\end{array}$ & {$[\mathrm{MPa}]$} & 16 & 18 \\
\hline$T \mathrm{~g}$ & {$\left[{ }^{\circ} \mathrm{C}\right]$} & 243 & 252 \\
\hline $\mathrm{CTE}$ & {$[\mathrm{ppm} / \mathrm{K}]$} & 49 & 49 \\
\hline
\end{tabular}

3.3. Mechanical properties after reliability tests To achieve high reliability, it is necessary to keep 
mechanical properties under reliability test conditions. Tables 3 and 4 show mechanical properties after reliability tests.

After thermal cycle treatment, AR-5100 kept its initial elongation and tensile strength. And, even after HTS, the degradation of the cured film was minor. This is attributed to the improved thermal resistance due to the elastomer-base resin interaction. AR-5100 showed adhesion strength over $500 \mathrm{~kg} / \mathrm{cm}^{2}$ and its failure mode was cohesive failure of the epoxy resin, suggesting that adhesion strength to $\mathrm{Cu}$ is strong enough.

Table 3. Mechanical properties after thermal cycle treatment.

\begin{tabular}{|c|c|c|c|c|}
\hline Properties & Units & Intial & $\begin{array}{c}500 \\
\text { cyc. }\end{array}$ & $\begin{array}{c}1000 \\
\text { cyc. }\end{array}$ \\
\hline Elongation & {$[\%]$} & 60 & 58 & 56 \\
\hline $\begin{array}{c}\text { Tensile } \\
\text { strength }\end{array}$ & {$[\mathrm{MPa}]$} & 160 & 158 & 156 \\
\hline $\begin{array}{c}\text { Young's } \\
\text { modulus }\end{array}$ & {$[\mathrm{GPa}]$} & 2.4 & 2.4 & 2.4 \\
\hline $\begin{array}{c}\text { Adhesion } \\
\text { strength to } \\
\mathrm{Cu}\end{array}$ & {$\left[\mathrm{kg} / \mathrm{cm}^{2}\right]$} & $>500$ & $>500$ & $>500$ \\
\hline
\end{tabular}

Condition: $-55^{\circ} \mathrm{C}$ to $125^{\circ} \mathrm{C}$

Thickness: $10[\mu \mathrm{m}]$

Table 4. Mechanical properties after HTS.

\begin{tabular}{|c|c|c|c|c|}
\hline Properties & Units & Intial & $\begin{array}{c}500 \\
\text { cyc. }\end{array}$ & $\begin{array}{c}1000 \\
\text { cyc. }\end{array}$ \\
\hline Elongation & {$[\%]$} & 60 & 54 & 49 \\
\hline $\begin{array}{c}\text { Tensile } \\
\text { strength }\end{array}$ & {$[\mathrm{MPa}]$} & 160 & 154 & 150 \\
\hline $\begin{array}{c}\text { Young's } \\
\text { modulus }\end{array}$ & {$[\mathrm{GPa}]$} & 2.4 & 2.5 & 2.5 \\
\hline $\begin{array}{c}\text { Adhesion } \\
\text { strength to } \\
\mathrm{Cu}\end{array}$ & {$\left[\mathrm{kg} / \mathrm{cm}^{2}\right]$} & $>500$ & $>500$ & $>500$ \\
\hline
\end{tabular}

Temperature: $150^{\circ} \mathrm{C}$

Thickness: $10[\mu \mathrm{m}]$

\subsection{Bias HAST test}

Results of bHAST are shown in Table 5. In general, breakdown tends to occur earlier with narrower line and space (L/S) patterns at bHAST. AH-3000 held out more than $300 \mathrm{~h}$ with wider $\mathrm{L} / \mathrm{S}$, but it broke down in $70 \mathrm{~h}$ with $\mathrm{L} / \mathrm{S}$ of $2 / 2 \mu \mathrm{m}$. In contrast, AR$5100 \mathrm{kept}$ insulation over $300 \mathrm{~h}$ even with L/S of $2 / 2 \mu \mathrm{m}$ and shows better bHAST resistance than AH-3000 (Fig. 2).
Table 5. Breakdown time at bHAST.

\begin{tabular}{|c|c|c|c|c|}
\hline \multirow{2}{*}{ Material } & \multicolumn{4}{|c|}{ Line/Space $[\mu \mathrm{m}]$} \\
\cline { 2 - 5 } & $2 / 2$ & $3 / 3$ & $5 / 5$ & $10 / 10$ \\
\hline $\begin{array}{c}\mathrm{AH}- \\
3000[\mathrm{~h}]\end{array}$ & 70 & 170 & $>300$ & $>300$ \\
\hline $\begin{array}{c}\text { AR- } \\
5100[\mathrm{~h}]\end{array}$ & $>300$ & $>300$ & $>300$ & $>300$ \\
\hline
\end{tabular}

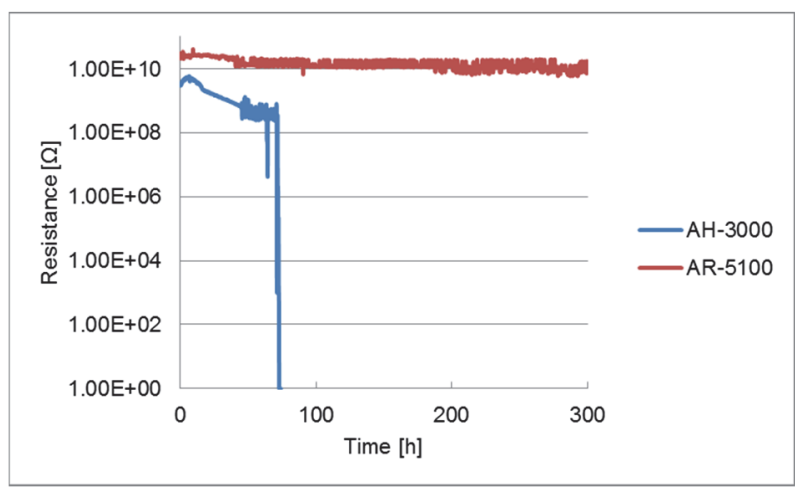

Fig. 2. Comparison of AH-3000 and AR-5100 in bHAST test $(\mathrm{L} / \mathrm{S}$ of $2 / 2 \mu \mathrm{m})$.

To investigate breakdown at bHAST, we observed the cross-sections of test pieces of bHAST (Table 6 ). With $\mathrm{AH}-3000, \mathrm{Cu}$ migration was observed around the $\mathrm{Cu}$ wirings. On the other hand, no $\mathrm{Cu}$ migration was observed with AR-5100 even after $300 \mathrm{~h}$ in bHAST. This improvement should result from the elastomer-base resin interaction due to increased quasi-cross liking density. This factor contributed to inhibition of water in bHAST leading to the inhibition of $\mathrm{Cu}$ migration.

Table 6. SEM image of AH-3000 and AR-5100.

\begin{tabular}{|c|c|c|}
\hline Material & AH-3000 & AR-5100 \\
\hline $\begin{array}{c}\text { Line/Space } \\
{[\mu \mathrm{m}]}\end{array}$ & \multicolumn{2}{|c|}{$2 / 2$} \\
\hline $\begin{array}{c}\text { bHAST Time } \\
{[\mathrm{h}]}\end{array}$ & 70 & 300 \\
\hline & & \\
\hline \\
$\begin{array}{c}\text { Cross-sectional } \\
\text { SEM image }\end{array}$
\end{tabular}




\section{Conclusion}

AR-5100 showed excellent resolution in wide thickness range from $5 \mu \mathrm{m}$ to $15 \mu \mathrm{m}$. AR-5100 kept good mechanical properties even after thermal cycle treatment or HTS. Especially, AR-5100 showed higher bHAST tolerance with $\mathrm{L} / \mathrm{S}$ pattern of $2 / 2 \mu \mathrm{m}$. AR-5100 was designed with film toughness improved by the new imide-elastomer and excellent lithographic properties by phenol resin. We believe that AR-5100 is promising as dielectric layers of advanced semiconductor packages.

\section{References}

1. M. Toepper, T. Fischer, T. Baumgartner, and H. Reichl, 2010 Proceedings $60^{\text {th }}$ Electronic
Components and Technology Conference (ECTC), (2010) 769.

2. T. Sasaki, J. Photopolym. Sci. Technol., 29 (2016) 379.

3. Y. Shoji, Y. Masuda, K. Hashimoto, K. Isobe, Y. Koyama, and R. Okuda, IEEE 66th Electronic Components and Technology Conference (ECTC), (2016) 1707.

4. A. Tanimoto, S. Nobe, and H. Matsutani, Abstract of $15^{\text {th }}$ The Symposium on Polymers for Microelectronics, (2012) 12.

5. A. Tanimoto, Y. Aoki, M. Kimura, S. Lee, T. Komine, Y. Okada, and M. Sasaki, J. Photopolym. Sci. Technol., 30 (2016) 231. 